\title{
ハッカ属植物の化学と生物学
}

清 水 純 夫 Sumio SHIMIZU 信州大学農学部農芸化学科

ヨーロッパでも東洋でも，ハッカはきわめて古くから 知られて打り，多くの文献が残されている(1,2)。 日本に おけるハッカの栽培は約 150 年前からといわれ(2), 1938 年ごろの生産量はハッカ取敊ろし油で 800 トンをこえて 世界最大のハッカ生産国となり，その天然メントールは 世界市場を制满した．1967年には，いったん200トンを こえる生産を示したが，ブラジルに挌ける圧倒的な生産 增加と合成メントールの急速な進展に伴い, 高メントー ル含量を特色とする日本ハッカは, 現在, 生産量 100 卜 ン以下に低迷している.

ハッカの研究といっても広沉な分野が山積して括り， ここでは, 化学というのは精油成分, テルペン類を中心 とすることとし, 生物学は分類, 細胞遺伝など関する ものに限って筆を進めることとしたい，筆者は，もとも と天然物化学の一分野として, “ッカ属成分の研究に入 った. ところが，現在，世界の各地で栽培されているハ ッカはほとんと種間雑種であり，応用面との結びつきを もつ種間雑種成分の研究は, 精油成分によるハッカ属の 分類や，精油成分の異なる両親から得られる雑種の遺伝 生化学など，基礎的な，乙か子境界分野の研究に深い関 係がある。

八ッカ属の植物は，一般に特有の香気を放ち，その成 分であるメントールは早くから結晶状に得られていた。 メントールの有機化学的研究, とくに異性体の立体構造 については, 系統的な研究がなされ，また精油中の微量 香味成分やセスキテルペンなど，多くの成分の研究が数 多く報告されている．これらについては多くの成書があ
り(3)，筆者も紹介を試みたこともあるので(4)，本稿では メントールを主成分としない多数の野生ハッカも含めて 紹介したい。

日本ハッカ (Mentha arvensis var. piperascens Mal.) は，高メントール系のハッカとして長く栽培され てきたが, 現在は耐病性, 高収油率の品種として, 後述 のように, 日本ハッカにオランダハッカ(M. spicata var. crispa Benth.）を交雑させて得られる種間雑種に代わ っている．日本ハッカには，(-) menthol を主成分と するもの以外に, (-) menthone, (+) pulegone, (-) piperitone oxide，piperitenone をとれぞれ主成分とす る成分型があり，それぞれの香気はまったく異なってい る. 日本ハッカと同様に, M. spicata, M.gentilis (種間 雑種ハッカの一種), その他多くのハッカについてる, それぞれに種々の成分型がある(4).

このように化学成分型により植物の分類を行なら化学 植物分類学(5) (chemical plant taxonomy, chemotaxonomy, chemosystematics) は，ガスクロマトグラ フィー, 薄層クロマトグラフィー，ガスクロマトグラフ ィー一質量分析法，高速液体クロマトグラフィーなそ， 最近急速な進展がみられる機器分析法がとり入れられる ようになった現在，新たな展開が期待される研究分野で ある(6).

ハッカの場合, chemotaxonomy の研究を複雑にする のは，多くの天然の種間雑種が見いだされるからである. 多くの種間の人工交雑によって池田が得た多数の雑種に ついて，筆者はその精油成分を分析した，その結果につ 
いては後述するが，精油成分の異なる両親の間の交雑は， 当然テルペソの生合成の問題と関連して研究すべき分野 である。

\section{1. ハッカ属植物の分類とその系統}

ハッカ属植物の分類については, 多くの研究成果が発 表されて括り，Briquetは2 亜属 15 種に分けている. これらには多くの変種があるほか，化学成分の異なる多 数の系が含まれている. また，種の間に自然交雑が起こ りやすく，いったん交雑が起こると，その雑種は不稔で あっても，地下茎で繁殖が可能であるため絶滅すること がなく、多くの天然の種間雑種が存在することになる.

したがって， 、ッカ属の分類は，植物分類学の中でも錯 雑して困難な分野の一つとされている. また，これらの 染色体数や減数分裂の観察についても，Schürhoff 以来, 内外の研究者により多くの研究が発表されたが, 必ずし も一致した結果に達しなかった. ハッカ属の染色体数に ついて, 従来の研究に異論が多いのは, 染色体が小さく, かつその数が多いことや，試料植物の鑑定そのものが困 難であることなどがその原因と考えられている。ここで は, Briquet の分類と，その亜属と節の形態的な性質を 表 1 亿示して物く ${ }^{(7,8)}$.

\section{表 1 ハッカ属の亜属と節}

I. Pulegium (Miller) Lamk. et Dc. (腋性の花序, 高 pulegone 含量)

節 1. Audibertiae Briq.

M. Requienii Benth. $\quad 2 n=18$

節 2. Euplegia Briq.

$$
\begin{array}{ll}
\text { M. Pulegium L. } & 2 n=48 \\
\text { M. Gattefossei Maire } & 2 n=48
\end{array}
$$

II. Menthastrum Cossom \& Germain

節 1. Spicatae L.（細長い頂生の花序）

節 2. Capitatae L. (球状または頭状の頂生の花序)

節 3. Verticillatae L.（腋性の花序）

池田は，ハッカ属種間の類縁関係や進化の過程を推定 するためにゲノム分析を行なっだ(7,9). 欧州にごく普通 に野生している M.rotundifolia は，図1飞示すように

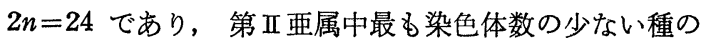
一つである. 彼はこの種を基本種と考光, 他種と交雑し て種間雑種をつくって雑種の減数分裂を観察し, 両親か ら由来した染色体の接合状況や雑種の稔性を調查して M. rotundifolia のゲノムと相手の種のゲノムとの異同 を調ぺ，同様な方法でハッカ属の多くの種のゲノムをつ ぎつぎに決定していった。

生物の形質を規制する遺伝子（gene）が，染色体上に 座を占めていることは周知のと特りである．生物が完全 な生活機能を営むために, 必要にして最少の染色体数か

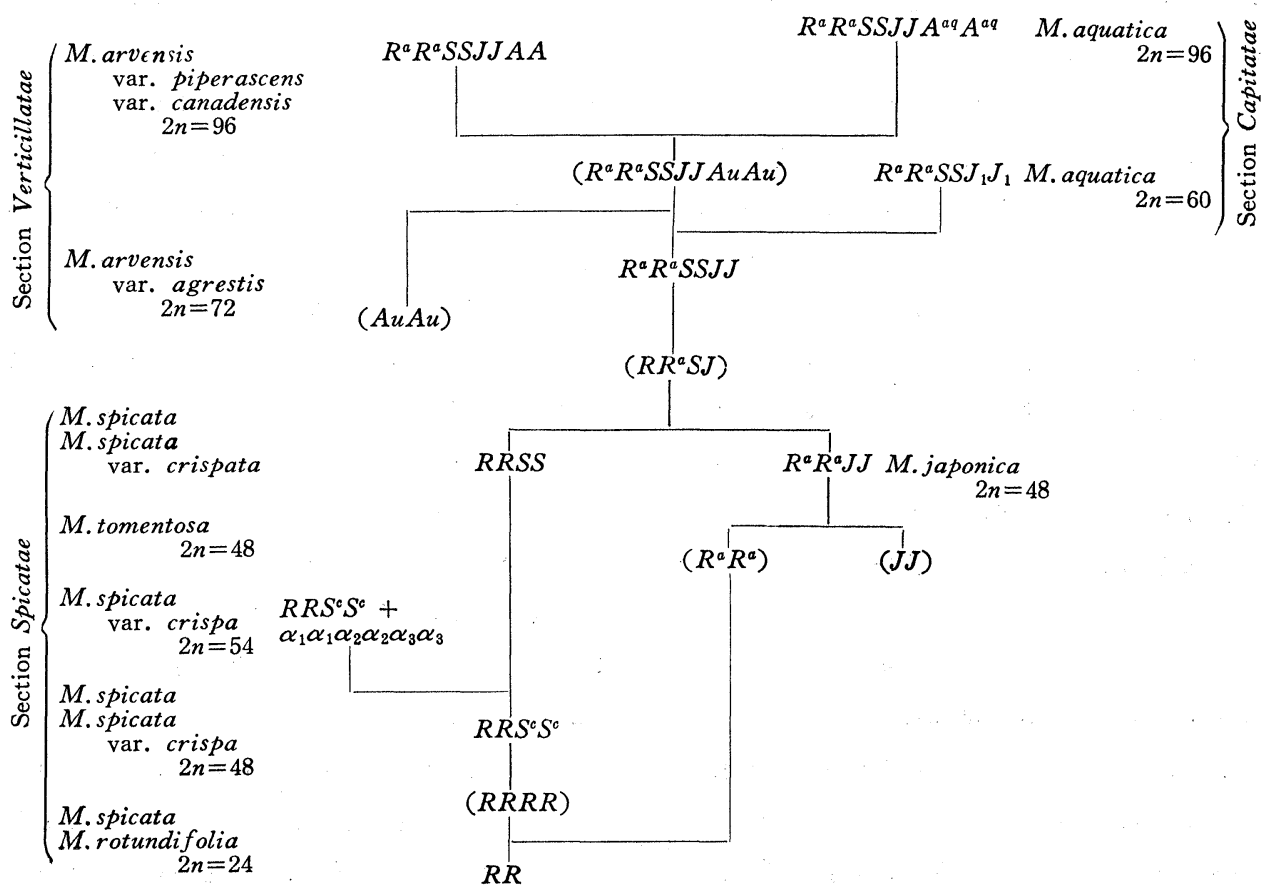

图 1 Menthastrum 覀属の推定系統澍（池田，小野，1969） 
ら構成された一組の染色体群をゲノムという：したがっ て，1 ゲノム中には生物が生活機能を営むのに必要な最 少限の遺伝子が含まれているわけである，倍数体でない 生物に括いては，ゲノムは半数 $(n)$ 染色体数と一致する. すなわち，配偶子は 1 ゲノム，体細胞は 2 ゲノムを有す る. 進化の途中で, ゲノムの倍化や異質ゲノムとの結合 によって，倍数体の種が生ずることがある. その場合に は，4 倍体が 4 個の， 6 倍体は 6 個のゲノムをすつよう になる。

ゲノム分析法の詳細は成書にゆずるが，図 1 はゲノム 分析の結果から推定された系統樹(9)である. ハッカ属の

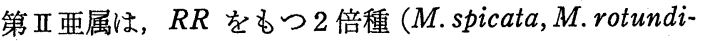
folia) から， 8 倍体の M. arvensis や M.aquaticaにま で進化していったものと推定される.図 1 の $R, S, J, A$ などはそれぞれ 12 本の染色体からなる独立のゲノムで あり, $S$ と $S^{c}, R$ と $R^{a}, A$ と $A^{a q}, J$ と $J_{1}$ はそれぞれ 内容の似たゲノム，すなわち部門相同ゲノムである．同 じゲノムや類似のゲノムを多くもつ種どうしは，互いに 近縁であるといえる。

表 1 に拈いて,第覀属は形態から 3 つの節 (Section) に大きく分けられているが，ゲノム分析の結果からみる と, Spicatae が他の両節から孤立し, Verticillatae, Capitatae の両節は形態上の相違にもかかわらず近縁で あり，日本に野生する M.japonica が Spicatae と他の 両節を結びつける “かなめ”ともいうべき種であること がわかる. さらに, M. piperita L. ( $2 n=72$ が多い) と M. gentilis L. $(2 n=72)$ はともに天然の種間雑種であっ $\tau$, 前者は M. aquatica L. $(2 n=96) \times M$. spicata L. $(2 n=48)$ に, 後者は M. arvensis $(2 n=96) \times M$. spicata $(2 n=48)$ に由来しているから, これらの類縁関係は拉 のずから明らかであろら(4b).

\section{2. ハッカ属植物の精油成分}

前述の池田らの研究によって染色体数, ゲノム構成の 明らかにされた各種のハッカにつき，その精油主成分に よる成分系 (chemical strains) で分類を試みたものが 表 2 である(4). フラボノイド，アルカロイドなどのよう に，植物の二次代謝生産物であるテルペン類は chemotaxonomy の対象としてとりあげられている，たとえば, モノテルペン類によるユーカリの分類が Penfold らに より(10)，ジテルペン類による Podcarpus などの分類が

\section{表 2 ハッカ属植物の染色体数と chemical strains}

a) M. rotundifolia $(2 n=24):$ i) piperitenone oxide 系, ii) neoiso-isopulegol, piperitenone 系, iii) piperitone oxide, epoxymenthylacetate 系

b) M.candicans $(2 n=24):$ i) sabinene hydrate 系

c) M.spicata $(2 n=24)$ : i) piperitenone oxide 系, ii) piperitone oxide 系, iii) menthone, piperitone 系, iv) dihydrocarvone 系

d) M. spicata $(2 n=48)$ : var. viridis, i) piperitenone oxide 系; ii) piperitone oxide 系, iii) piperitone 系, iv) pulegone 系; var. longifolia, i) piperitenone oxide 系, ii) piperitone 系, iii) carvone 系; var. crispa, i) piperitenone oxide 系, ii) pulegone 系, iii) carvone 系 $(2 n=36)$; var. viridis, i) carvone 系; var. longifolia, i) piperitone oxide 系, ii) carvone 系, iii) linalool 系

e) M. japonica $(2 n=48):$ i) menthone, pulegone 系

f) $M$. arvensis var. agrestis $(2 n=72):$ i) 3-octanone 系

g) M.arvensis var. praecox $(2 n=72)$ : i) pulegone, 3octanol 系

h) M.arvensis var. piperascens $(2 n=96)$ : i) menthol 系, ii) menthone 系, iii) pulegone 系, iv) piperitone 系, v) piperitenone 系, vi) piperitone oxide

i) M. aquatica $(2 n=96):$ i) linalool 系 $(=M$. citrata $)$, ii) menthofuran 系, iii) iso-pinocamphone 系

j) M. gentilis ( $2 n=72$, 天然の種間雑種) : i) carvone 系, ii) menthol 系, iii) menthone 系, iv) pulegone, menthone 系, v) linalool, menthone 系, vi) pulegone, piperitone oxide 系, vii) piperitenone oxide, pulegone

Erdtman により，早くから研究されてきた(11). テルペ ン類は類似の構造の複雑な混合物であり，それぞれに数 多くの立体異性体が知られているので, 多数試料の比較 分析には長期間の研究が必要な分野であった. Rudloff が述べているように(6)，植物成分のうち，モノテルペン， セスキテルペン類については，ガスクロマトグラフィー の進展により, chemotaxonomy の展開が期待される.

藤田は，主として精油を含む多くの植物について， chemotaxonomy に関する報告を行なってきた(12)が，単 なる成分の検索の集積にとどまることなく，これらの成 分をつなぐ生成様式を強調している(12b).

表 2 にみられるように, 染色体数の多少にかかわりな く, menthone, pulegone, piperitone oxide の主成分 はしばしば見いだされる。したがって，単なる主成分の 含量のみからでは, ハッカの系統や種についての推察は きわめて困難である. menthofuran は従来, piperita 油 の特有成分として arvensis 油と区別されて特り, この 成分は pulegone から in vitro に生成することが確か められている(13). pulegone は広く各種のハッカに見い だされるが, menthofuran 高含量のハッカにはaquatica が知られている. aquatica. には isopinocamphone 系 も存在するが, menthofuran 系のものをえらんで men- 
子 पone 系の spicata と交配して得られる $\mathrm{F}_{1}$ の精油は, ミッチャムハッカ油に近い精油組成を示し(30)，乙かも piperita は aquatica と spicata との天然の種間雑種で あるので(4b,31), menthofuran は成分の面で aquatica と piperita の関連を示するのといえよう.

3-Octanone を主成分とする欧州 arvensis は，後述の ようにこれを一方の親とする多くの $\mathrm{F}_{1}$ の精油に 3octanol が含まれ(14)，これは日本 arvensis にも少量見 いだされて括り，両者の関連が $\mathrm{C}_{8}$ 成分生成経路を通し て推定される.

しかし，一般的に， chemical strains はハッカ属に和 ける種の内部のこまかい分類には役だつが，種の系統ま でを推定することは困難であり，種の系統や進化の研究 のためには，外部形態学，゙゙ノム分析を含む細胞核学的 研究と,成分分析との協力によることがのぞまれる.ハッ 力属には多くの種間雑種が存在し, 成分系も menthone, carvone, pulegone, piperitone oxide が数多く主成分 として見いだされ，成分のみでは雑種かどらかの判定は きわめて困難である，この場合でも，成分分析を行なら 際に対象試料のみでなく，推定できる両親についての成 分型と, さらにそれらの $\mathrm{F}_{1}$ の成分の分析を併行して比 較検討する方法によれば，細胞核学的知見と合わせて， 系統の推定をより確実なるのとすることができる.

通常, 精油分析による chemotaxonomyは, 開花始め の試料を用いて行ならが, 採取時期が異なったり環境が 変わったりすれば, 種によっては成分の変動が当然予想 される. 表 2 の rotundifolia のiii)の系は, 夏期の開花始 めには主として piperitone oxide であり, epoxy-menthylacetate が前者とほぼ等量になるのは 10 月以降に得 られる精油であった (15). candicans の精油主成分は, 一 キサン抽出ではほとんど sabinene hydrate のみである が, 通常の水蒸気蒸留法の精油では, これの転位反応生 成物, terpinen-ol-4 が混入してくる例が筆者らの研究 で明らかになった(29). したがって, 場合によっては蒸留 法による精油成分を溶剤抽出したものと比較検討しなけ ればならないこともあるから，注意を要する。

\section{3. ハッカ属の種間雑種の精油成分}

テルペン類の生合成経路の研究には, ${ }^{14} \mathrm{C}$ ラペル化合 物によるトレーサー法が圧倒的に多く，ハッカ属植物を 用いた報告は Banthorpe の総説 ${ }^{(13)}$ にまとめられている.

\section{表 3 栽培ハッカ品種の变遷（北海道農試）}

\begin{tabular}{|c|c|c|c|c|c|c|c|}
\hline 品種名 & $\begin{array}{l}\text { 品種 } \\
\text { 決定 } \\
\text { 年 }\end{array}$ & $\begin{array}{l}\text { 10a当り } \\
\text { 収油量 } \\
\text { (kg) }\end{array}$ & $\begin{array}{l}\text { 叕油 } \\
\text { 量の } \\
\text { 比 }\end{array}$ & $\begin{array}{l}\text { 脳分 } \\
(\%)\end{array}$ & 育 & 成 & 法 \\
\hline あかまる & 1924 & 3.12 & 100 & 46 & \multirow{6}{*}{\multicolumn{3}{|c|}{$\begin{array}{l}\text { 日本ハッカの系統選抜 } \\
\text { 日本ハッカの系統選抜 } \\
\text { 中国ハッカ } \\
\text { 中国ハッカ本ハッカ } \times \text { 日本ハッカ } \\
\text { M.spicata } \times \text { 日本ハッカ } \\
\text { M.spicata (ドイッ系) } \\
\text { ×日本ハッカ }\end{array}$}} \\
\hline ほくしん & 1938 & 3.37 & 108 & 58 & & & \\
\hline まんよう & 1953 & 5.14 & 164 & 56 & & & \\
\hline すずかぜ & 1954 & 5.06 & 162 & 59 & & & \\
\hline おおば & 1962 & 6.37 & 203 & 46 & & & \\
\hline ほうよう & 1965 & 11.64 & 373 & 54 & & & \\
\hline あやなみ & 1968 & 14.39 & 461 & 52 & \multicolumn{3}{|c|}{$\begin{array}{l}\text { 日本ハッ力 }(\mathrm{S} 1-1) \times \\
\text { M.spicata var. crispa }\end{array}$} \\
\hline
\end{tabular}

生合成経路の研究法としては，この他に放射線処理など で精油成分が変化した変異種を用いる方法や，成分の異 なる両親の間に種間雑種をつくり，その $\mathrm{F}_{1}, \mathrm{~F}_{2}$ などの 精油成分を分析して生合成経路を考究する方法などがあ り，最近までに後者の方法による報告がかなりある. ト レーサー法による成果については後述し，ここでは種間 雑種を用いた例を述べることとする.

筆者らも, 日本ハッカの menthol 主成分のものと carvone 主成分の spicata とを組合わせ，多くの $F_{1}$ を つくって精油分析を行なった，その結果，carvone 主成 分のものが多く現われ, menthol 主成分の $\mathrm{F}_{1}$ では, メ ントール含量 $75 \%$ をこえ, 耐病性も強く, 育種上注目 に価するものも見いだされた(16). 表 3 は, 今日まで北海 道で栽培された品種の変遷を北海道農試の笠野(17) がま とめたもので, これによっても明らかなように, 現在, 日本ハッカ $\times$ spicata $の \mathrm{~F}_{1}$ として得られた新品種「あや なみ」は，収油量も以前の「あかまる」の 5 倍に近く， 脳分も高いことが知られる.

この点について, 米国の Murray は, carvone を主 成分とするチリメンハッカ (spicata var. crispa, $2 n=$ 48）の自殖により得られる多数の $F_{1}$ の精油型は, carvone, dihydrocarvone 系（パラメンタン環の 2 位の酸 化物) と pulegone, menthone 系 (パラメンタン環の 3 位の酸化物）との比が $3: 1$ に近いことから,メンデル 性因子が関与する分離比にあたるものと考え, carvone 生成の gene $C$ は pulegone などの生成に関与する gene $c$ に対して優性であるとすれば説明できることを 明らかにした ${ }^{(19)}$. 筆者らも, carvone 主成分で日本に野 生するオランダハッカ $(2 n=48,2 n=54)$ の異なる系統 間の交雑により得られる $F_{1}$ の精油型に, carvone 系以 外に, trans-carveol 亲, piperitenone oxide 系を見い 


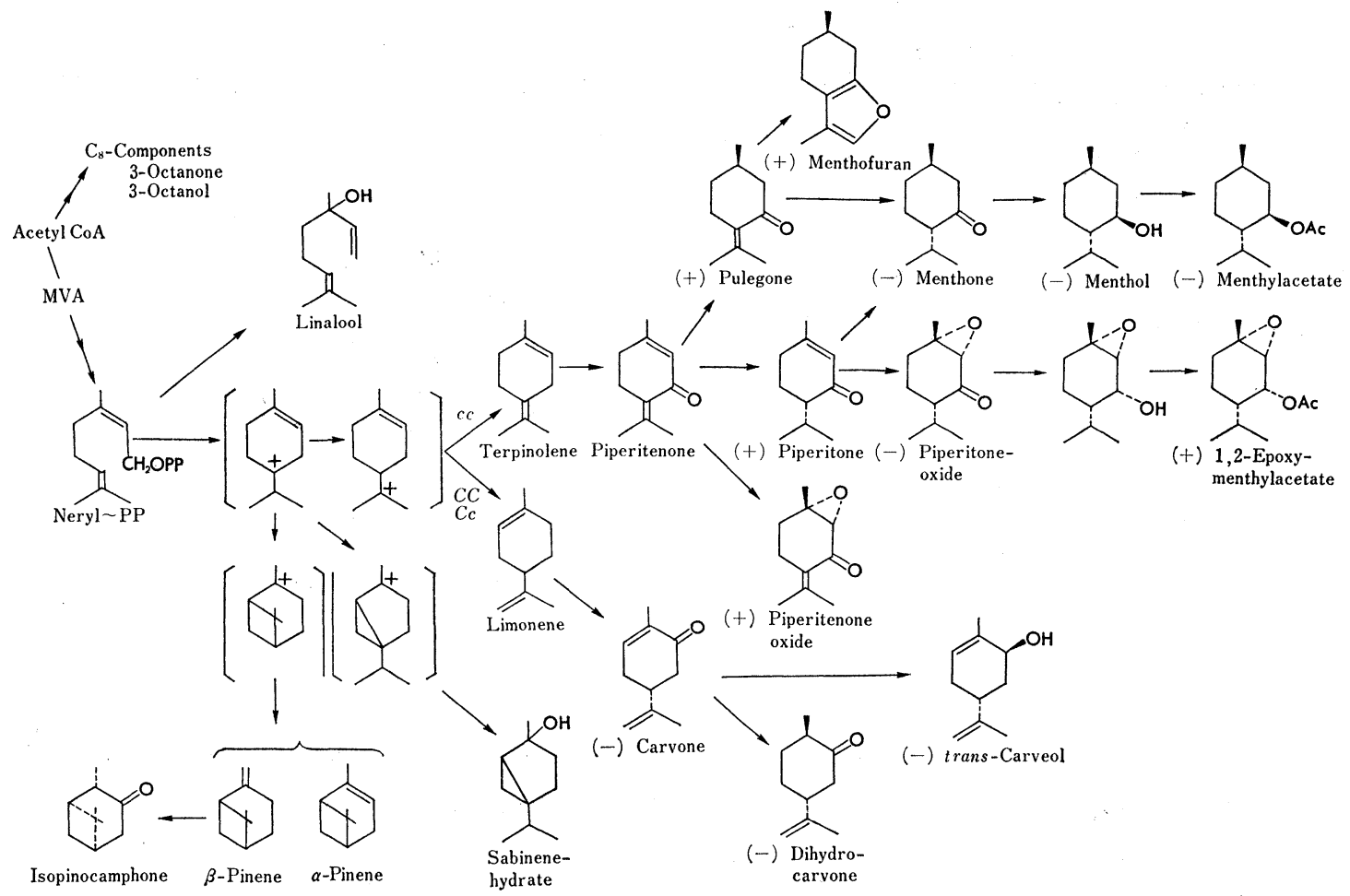

図 2 ハッカ属のモノテルペン類の生成様式

だした，後者は piperitenone に由来すると考えられる から，Murray の説 (carvone 方向と menthone 方向 に分岐する因子が関与する）と大すじに括いては同様の 結果になる(21).

rotundifolia と carvone 主成分の spicata との交雑 により得られたものでは, piperitenone oxide の出現頻 度が高いので, oxide 類生成にはなお別の要因が関与し ているのでないかと考兄られる. 図2は，ハッカ属にみ られるテルペン類について, 多くの研究者により出され た生成経路 ${ }^{(13,18 b)}$ K, piperitenone oxide, 1,2-epoxymenthyl acetate ${ }^{(15)}$ ，などの絶対構造の明らかになった ものの生成についても推定して追加したものである.

一方, 日本八ッカについて, 岡山農試の中山ら ${ }^{(20)}$ が自 殖あるいは交配により，一メンデル因子遺伝に括いては $3: 1$ 飞分離する結果を手がかりとして, 精油生成に関 与する遺伝子の推定を行なった．その要点は以下のとう りである.

(1) menthol 系と menthone 系との交雑の $F_{1}$ はすべ て menthol 系で, $F_{2} て ゙$ menthol 系と menthone 系 とが $3: 1$ と分離する.

(2) menthone 系の自殖 $S_{1} か ゙ ，$ menthone 系と pule- gone, menthone 系に分離する。 また，別の menthone 系 $S_{1}$ に menthone と piperitone $3: 1$ 飞分離する ものがある。

(3) piperitenone を含まない pulegone-menthone 系 の $S_{1}$ に piperitenone が現われる.

(4) piperitone 系の $S_{1}$ 飞 piperitenone 系を多含する 系統が現われる。

(5) piperitone 系の自殖 $S_{1}$ に piperitone 系と piperitone oxide $3: 1$ に分離するものがある.

これらの結果は, ハッカ属精油成分の生合成に関する 諸実験にもとずいて提出された図 2 の主要モノテルペン 類の生成経路と，矛盾するところはないと考号らる.

日本に野生するハッカであるとメハッカ(M.japonica) の主要成分は, menthone, pulegone であり,これと日 本ハッカとの交雑による人工種間雑種 $(2 n=72)$ を池田 らが得たので，その精油成分を筆者らが分析し，i） menthone-menthol-pulegone 系 $(36,26,21 \%)$, ii) pulegone-menthone 系 $(57,30 \%)$, iii) menthone 系 （86\%）の 3 型に分類した ${ }^{(22)}$ ）その後，東北，北関東の 8 県にわたって野生ハッカを調査したところ，[A] 型 (日本ハッカ, arvensis, $2 n=96)$ と [B]型 $(2 n=72)$ の 
表 4 3-Octanone 主成分欧州 arvensis を含む種間雑種の精油成分

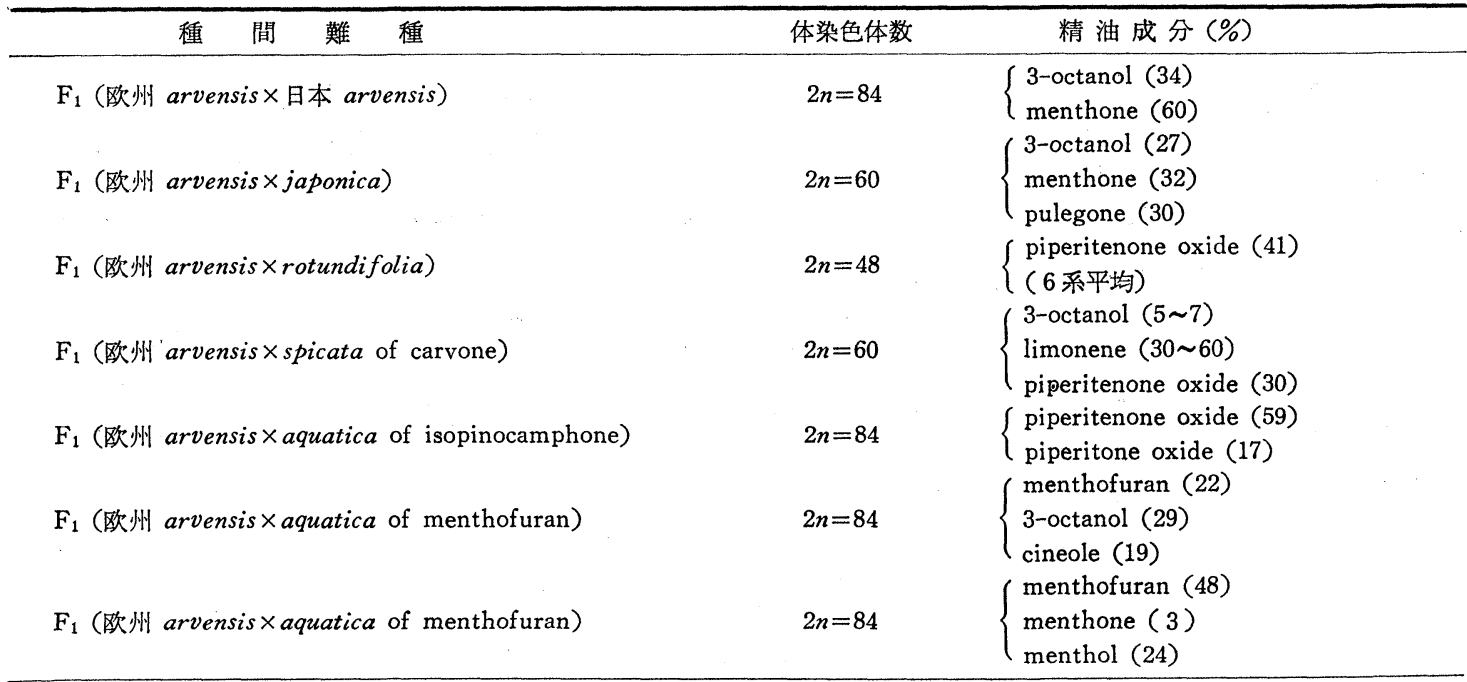

2 種の存在が明らかとなり，このうち[B]型は arvensis と japonica の天然の種間雑種であることを，外部形態 による観察と細胞学的な性状により推定した。ささらに, 野生の [B] 型の精油型は, 人工種間雑種の 3 精油型之 ほぼ同様であることがわかった。このような天然種間雑 種が存在することは, 東北地方に古くから生育していた [A] 型の野生 arvensis のなかの高メントール系が，日 本ハッカの先祖につらなるものと筆者らが推定する理由 の一つである(22).

表 2 の成分系のらち, arvensis で 3-octanone を約 90\% 含有する系統をあげたが，これは欧州に見いださ れた $2 n=72$ の系である. 表 4 に示すよらに, この欧州 arvensis と他のハッカとの交雑により得られる $\mathrm{F}_{1}$ の精 油に，3-octanol がしばしば見いだされることから， $\mathrm{C}_{8}$ 成分の遺伝性が強いものと推定され(14)，図 2 に acetyl $\mathrm{CoA}$ から $\mathrm{C}_{8}$ 成分の経路を加えた。 また， isopinocamphone 主成分の aquatica と他のハッカとの $\mathrm{F}_{1}$ の精油 に, limonene, $\beta$-pinene などの高含量系統がしばしば 見いだされるなどから，isopinocamphone に至る経路を 図2のように推定した。

\section{4. ハッカの油腺とテルペン生合成}

ハッカ属に括けるテルペン類の生合成について, ${ }^{14} \mathrm{C}$ ラベル化合物のとり込み実験により，次のような生合成 経路がわかった(13,23). mevalonic acid (MVA) isopentenyl pyrophosphate (IPP) $\longrightarrow$ dimethylallyl pyrophosphate (DMAPP) を経て neryl pyrophosphate または geranyl pyrophosphate に至り，前者は閉環し てモノテルペン類に，後者はセスキテルペン類などにな る. 最近, Loomis は, piperita の 2 葉付の切茥を用 い, MVA-2-14C の場合はモノテルペン部へのとり込み 率は低いが，セスキテルペソ部には，0.33\% ${ }^{(24)},{ }^{14} \mathrm{CO}_{2}$, glucose-U-14C の場合にはモノテルペン部に $0.38 \%$ な どとよくとり込まれることを見いだした。

この実験でとり込まれた ${ }^{14} \mathrm{C}$ ラベル化合物は，モノテ ルペンとしては pulegone を, セスキテルペンとしては caryophyllene をそれぞれ分取し，その酸化分解物の検 索から分子中の ${ }^{14} \mathrm{C}$ の位置をしらべたところ, pulegone に招いても, caryophyllene に括いても, ${ }^{14} \mathrm{C}$-IPP が選 択的にとり込まれていることを示していた.つまり， ${ }^{14} \mathrm{C}$ を含まない内部の DMAPP 源があり，それに由来する DMAPP が，外から与えられた ${ }^{14} \mathrm{C}$ を含む IPP と反応 し，テルペン生成に至るすのであろうと推定された(24). ${ }^{14} \mathrm{C}-\mathrm{MVA}$ のモノテルペン部へのとり込みは，ハッカ においてきわめて低いことが， compartmentalization 効果* として知られていた ${ }^{(27)}$. その説明として，細胞 膜の透過性によると考えることもできるが，さらに進ん で, 葉緑体で光合成の行なわれる部位と, テルペン生合 成の行なわれる部位との関連を考えれば， ${ }^{14} \mathrm{CO}_{2}$ に由来 する光合成物は，とり込みに有効ではあるが，外部から

＊異なった部位に異なった生合成経路が局在化することによ り起こる異常性. 


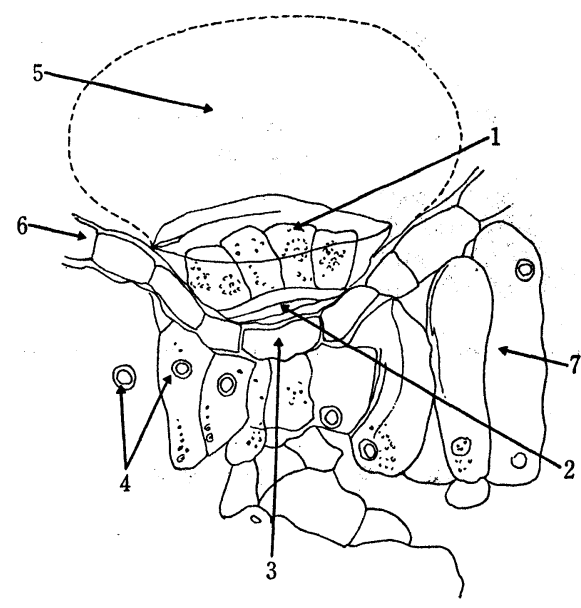

図 3 日本ハッカの油腺 (腺鱗) 構造

1. 冠部細胞 2 . 柄部細胞 ( 3 層よりなる) 3. 基 部細胞 4. 葉肉組織中の油滴 5 . 油胞細胞 (点線 の部分, 破れて油滴はない） 6 . 葉の表皮 7 . 栅状 組織 (池田長守原図)

加えた MVA-2-14C は，テルペン生合成の部位に到達し 難いであろちと考えられるのである. 一方, トリテルペ ンは, piperita に执いても MVA-2-14C が単時間内に とり込まれて, ${ }^{14} \mathrm{C}$ の位置がイソプレン則に従って入っ た squalene が生成する.これは 4 時間くらいで急速に 減少するとともに, トリテルペン類, sitosterol などの 生成に向からことが知られて扣り ${ }^{(25)}$, 同様の結果が, spearmint のカルスを用いる実験 ${ }^{(26)}$ でも報告されてい る.

パラの花弁では, MVA-2- ${ }^{14} \mathrm{C}$ が geraniol, nerol な どのテルペンアルコールとその $\beta$ 配糖体によくとり込ま れることが知られている(23)，Amelunxen は，バラの花 弁の精油生成部位が, 隣接細胞の解糖系からのエネルギ 一供給を受けやすく, また外部の空気にふれやすい構造 であることを, その組識の電顕観察から述べている(24).

Burmeister と von Guttenberg(28) によれば, piperita の精油は嫌気的な過程で生成され, 葉部の裏面にあ る油腺（図 3）に貯蔵される. 貯蔵部位は腺鱗と腺毛の 2つに分けられ，低濃度酸素の環境に適応するためと考 えられている. 腺鱗は腺毛より形が大きく，精油量も多 W.

精油中にとり込まれた ${ }^{14} \mathrm{C}$ 成分の消長をしらべると, 活発な代謝が行なわれており, 光合成と呼吸に深い関連 があるのではないかということを最近の研究が示してい る. Amelunxen の電顕による piperita の研究によれ
ば, その油腺の構造は, バラの場合と対照的で, 解糖作 用によるエネルギーの供給から孤立した部位にあり，し かも嫌気的な状沅にあるという(24). この構造は, piperita に括ける compartmentalization の原因と結びつけられ る. Loomis はさらに, MVA-2-14C のセスキテルペン 部へのとり込みが, 鹿糖を添加した場合, 無添加のるの に比較して約 3 倍近い増加があることを報告(24) して拉 り，上記の考えを支持するものであろう．彼はさらに， 同じハッカで光と温度の効果を検討し，昼間 14 時間, $25^{\circ} \mathrm{C}$ で夜が低温 $\left(8^{\circ} \mathrm{C}\right)$ のときは menthone 含量が高い が，夜が高温 $\left(25^{\circ} \mathrm{C}\right)$ になると呼吸が活発になり，その 結果 menthofuran, pulegone が高まることなどを報告 した(18b).

いずれにしても，油腺中内貯蔵成分として考えられて きた種々のテルペン類は，その変動が活発であり；光合 成，呼吸などとの関連がきわめて密接であることがしだ いに明らかになってきた。しかし，この研究に用いられ たハッカは，還元の進んだと考えられる menthol を含 む piperita であること，ハッカ属は前述の通り， menthofuran 主成分の aquatica や piperitenone oxide 主 成分の rotundifolia などがあり，後者は時期別です， 葉位別です，その oxide 含量には著しい変動がみられ ないことなどの問題がある、このような酸化物と考えら れる成分を主成分 (90\%近い) とするハッカは, piperita と同様な嫌気的状況でテルペン生成を行なうのかどうか, その油腺の構造と機能はどのようなものであるのかなど， 精油生成機構に和ける基本的問題の解明にも役立つので ないかと期待される。

なお，図2に示した経路について，Bourbott，Croteau， Shine, Loomis は 6th International Congress of Essential Oils (Sanfransisco, Sept. 9th, 1974) において, cell free extract により neryl-PP から $\alpha$-terpineol を経て terpinolene, limonene が生成すると報告した.

本稿執筆にあたり, ハッカ属の分類, 染色体数, ゲノム分 析など, 種々の御教示を受けた池田長守博士に厚くお礼申し 上げます.

\section{文献}

1) E. Guenther: "The Essential Oils" III, D, van Nostrand, 1949 , p. 586, p. 641, p. 658.

2）池田長守: “薄荷 - 除虫菊”, 養蜸堂, 昭 27， p. 45 .

3) J.L. Simonsen: "The Terpenes", Vol. I, Cambridge Univ. Press 1953, p. 230; Rodd's Chem. of Carbon Compounds, Elsevier, II-B, 1968, p.184.

4a）清水純夫: 化学, 22, 67 (1966). 
4b）清水純夫 : 化学と生物, 3, 73 (1965).

5) IUPAC : Chem. of Natural Products, 4, Chemical Taxonomy, 1966, p. 169.

6) E. von Rudloff: "Recent Advances in Phytochemistry", North-Holland Pub. Co., 1969, p.127.

7）池田長守：“細胞遗伝学的方法による薄荷属植物の育種学 的研究, 岡山大学学位論文, 1961 .

8) M.J.Murray et al.: J.Heredity, 62, 363 (1971).

9) 池田長守, 小野清六: 育種学雑誌, 19, 357 (1969).

10) R. Hegnauer: "Chemotaxomie der Pflanzen", Birkhäuser Verlag, Bd.V, 1969, p. 167.

11) M.Florkin \& H.S. Mason : "Comparative Biochemistry”, III-A, Academic Press, 1962, p.615.

12a) M.Florkin \& H.S. Mason : "Comparative Biochemistry”, III-A, Academic Press, 1962, p.624.

12b) 藤田安二 : 生物科学, 24, 80 (1972).

13) D.V. Banthorpe et al.: Chem. Reviews: 72, 115 (1972).

14）清水純夫, 池田長守, 上田博夫, 星野和美 : 農化, 36, 913 (1962).

15). H.Shibata \& S.Shimizu : Agr. Biol. Chem., 37, 2675 (1973); 長沢 徹, 梅本和泰: 農化, 48, 39 (1974).

16）池田長守，清水純夫：香料， $58 ， 25$ (1960).

17）笠野秀雄：北農， $41 ， 3$ (1974); ‘大型機を中心とする八 ッカ栽培技術体系'，北農 (特集号), 1971 .

18a) M. J. Murray: Genetics, 45, 925 (1960); “Rodd's Chem. of Carbon Compunds" II-E, 1971, p. 74.

18b) W.D. Loomis: "Terpenoids in Plant", (ed.) Prindham, Academic Press, p. 59.

19) D.V.Banthorpe et al.:Chem. Rev., 72, 119, 123 (1972).

20）中山孟郎, 松川正行, 安藤昭一：暖地ハッカに関する研 究, 農林水産技術会議, 1971, p. 52 .

21) S.Shimizu: J. Fac.Agr., Shinshu Univ., 9, 73(1972).

22）清水純夫, 池田長守: 香料, 67, 17 (1972); 池田長守, 清水純夫, 唐沢伝英, 折笠常弘: 育種学雑誌, 18, 273 (1968); 岡山大学学術報告, 36, 1 (1970);37, 1(1971).

23) M.J.O. Francis: "Aspects of Terpenoid Chemistry and Biochemistry", (ed.) T.W. Goodwin, Academic Press, 1971, p. 35.

24) W.D. Loomis: "Recent Advances in Phytochemistry", Vol. 6, Academic Press, 1973, p. 147.

25) R.Croteau \& W.D.Loomis: Phytochem., 12, 1957 (1973).

26）菅隆幸ら：第 17 回香料テルペン精油化学に関する討論会 要旨集, 104 (1973).

27）野副重男訳 : “ビューロック，天然有機化合物の生合成”, 広川書店, 1967, p.76.

28) J.Burmeister \& H.von Guttenberg : Planta Med., 8, 1 (1960) ; W. D. Loomis: "Recent Advances in Phytochmistry", Vol.6, Academic Press, 1973, p. 180.

29）清水純夫, 唐沢伝英: 第 12 回香料テルペン精油化学に関 する討論会要旨集, 28 (1968).

30) M.J. Murray et al.: Can. J. Genet. Cytol., 14, 13 (1972).

31）宇渡清六, 清水純夫, 池田長守 : 岡山大学農学部学術報 告, 20,1 (1962).
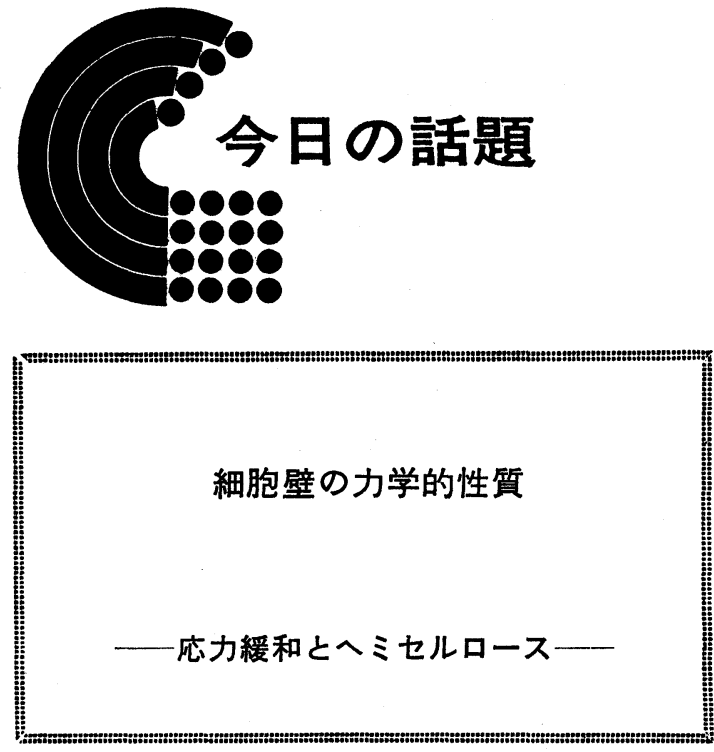

マカラスムギの幼葉鞘を暗所で育てると, 約 $1 \mathrm{~cm}$ の 長さになるまでは細胞分裂がおこって細胞が増えるが， その後細胞分裂は括こらないで伸長し, 約 $6 \mathrm{~cm}$ の長さ にまで達する.この段階では，細胞漫透圧によって単に 細胞外から水を吸いこんで伸長する．このため，植物の 細胞では大きい液胞とよばれる水のタンクが発達してい る.このような水ぶくれともいらべき植物細胞の生長に おいては，細胞壁が大きい役割をはたしている，つまり， 細胞の吸水生長は細胞壁がのびることによって行なわれ る.

周知のように，植物ホルモンのひとつであるオーキシ ンは，細胞の伸長を誘導する．との際，オーキシン処理 によって細胞壁がゆるむことが知られている．また，細 胞の浸透圧がオーキシン処理によって高まっているとい ら証拠はなく, 細胞の伸長生長は細胞壁がゆるむことに その原因があると考えられる。

1930年代から, 細胞壁のゆるみを測定する方法が各種 考案されてきた. 例をあげると, 茎切片などの両端をひ っぱる方法, 切片を水平に保って一端を固定し, るら一 端に打もりをかけて曲がりかたを測定する方法，あるい は外からひっばったりおるりをかけたりせずに，外部溶 液の漫透圧を上げることによって細胞が内部から細胞壁 を押す力を減少させ，これによって細胞壁の力学的性質 を測定しようとする原形質分離法などがあった。これら の方法では “弾性”打よび “塑性”とよばれる值が得ら れた. “弾性”は, 細胞壁が細胞内から力をうけるとき 